Vol. 10 (2001): 153-163.

\title{
Freezing and low temperature photoinhibition tolerance in cultivated potato and potato hybrids
}

\author{
Mervi M. Seppänen \\ Department of Applied Biology, PO Box 27, FIN-00014 University of Helsinki, Finland. Current address: \\ Department of Natural Resource Sciences and Landscape Architecture, 2125B Plant Sciences Building, \\ University of Maryland, College Park, USA, e-mail: mervi.seppanen@helsinki.fi \\ Oiva Nissinen \\ MTT Agrifood Research Finland, Lapland Research Station, Tutkijantie 28, FIN-96900 Saarenkylä, Finland \\ Saija Perälä \\ Department of Applied Biology, PO Box 27, FIN-00014 University of Helsinki, Finland
}

Four Solanum tuberosum L. cultivars (Nicola, Pito, Puikula, Timo) and somatic hybrids between freezing tolerant $S$. commersonii and freezing sensitive $S$. tuberosum were evaluated for their tolerance to freezing and low temperature photoinhibition. Cellular freezing tolerance was studied using ion leakage tests and the sensitivity of the photosynthetic apparatus to freezing and high light intensity stress by measuring changes in chlorophyll fluorescence $\left(\mathrm{F}_{\mathrm{V}} / \mathrm{F}_{\mathrm{M}}\right)$ and oxygen evolution. Exposure to high light intensities after freezing stress increased frost injury significantly in all genotypes studied. Compared with S. tuberosum cultivars, the hybrids were more tolerant both of freezing and intense light stresses. In field experiments the mechanism of frost injury varied according to the severity of night frosts. During night frosts in 1999, the temperature inside the potato canopy was significantly higher than at ground level, and did not fall below the lethal temperature for potato cultivars (from -2.5 to $-3.0^{\circ} \mathrm{C}$ ). As a result, frost injury developed slowly, indicating that damage occurred to the photosynthetic apparatus. However, as the temperature at ground level and inside the canopy fell below $-4^{\circ} \mathrm{C}$, cellular freezing occurred and the canopy was rapidly destroyed. This suggests that in the field visual frost damage can follow from freezing or non-freezing temperatures accompanied with high light intensity. Therefore, in an attempt to improve low temperature tolerance in potato, it is important to increase tolerance to both freezing and chilling stresses.

Key words: freezing tolerance, frost injury, photoinhibition, potatoes, somatic hybrids 
Seppänen, M.M. et al. Frost tolerance of potato

\section{Introduction}

Frost is a freezing temperature that damages cultivated plants (Pessi 1960). Severe frosts occur when the temperature at ground level falls below $-3^{\circ} \mathrm{C}$ (Solantie 1987). Cultivated potato, Solanum tuberosum L., is a freezing or frost sensitive species and is severely injured at temperatures below $-3^{\circ} \mathrm{C}$ (Chen and $\left.\mathrm{Li} 1980\right)$. Therefore, severe frosts, which interrupt the growing season in August in Finland, can reduce potato yields (Valmari 1965). According to meteorological data, late autumn frosts and spring frosts cause less damage in Finland than early autumn frosts (Pessi 1958, Valmari 1965).

Frost damage can be prevented to some extent by using appropriate cultivation practices. Early planting and pre-germination of potato seed tubers speed up growth and lengthen the growing period. By choosing suitable locations and soil types, the severity of frost damage can be reduced (Valmari 1965). Sufficient nitrogen fertilisation can also reduce frost damage to potato by increasing leaf area and ability to capture heat radiating from the soil during a frost. A larger undamaged leaf area also enhances the recovery processes and ensures growth continuation after frost (Valmari 1959). In practice, nitrogen fertiliser is applied to optimise potato yield and quality and prevent frost damage.

Freezing tolerance among $S$. tuberosum cultivars does not vary significantly. There are, however, many wild potato species, including S. commersonii, which can tolerate $-4.5^{\circ} \mathrm{C}$. $S$. commersonii also has the ability to cold acclimate, that is to improve freezing tolerance when exposed to low, non-freezing temperatures (Chen and Li 1980). S. tuberosum cultivars are freezing sensitive and unable to cold acclimate. This has increased interest in transforming $S$. $t u$ berosum germplasm using genes from freezingtolerant wild potatoes. Cardi et al. (1993) produced the somatic hybrid SH9 (S. commersonii $\mathrm{P} 1243503$ (+) S. tuberosum SPV11) that is more cold tolerant than the $S$. tuberosum SPV11 parental line. A hybrid progeny segregating for freezing tolerance and acclimation capacity was produced by selfing the somatic hybrid SH9A (Seppänen et al. 1998). Those results indicated that the freezing tolerance of hybrid parents can be completely restored in the selfed progeny and genotypes with as good freezing tolerance as $S$. commersonii were identified.

Frost injury in the field develops slowly implying that the primary injury takes place in the photosynthetic apparatus (Steffen and Palta 1989b). Injury to the photosynthetic apparatus causes photoinhibition, a reduction in photosynthesis in the presence of light (Krause 1994). At low temperatures the energy flow from the photosystem may exceed the demand of metabolic pathways and lead to excess excitation in the chloroplasts. In general, growing conditions that include frosts suppress photosynthetic carbon metabolism and increase the potential for overexcitation of the photosynthetic apparatus, and thus result in photoinhibition (Huner et al. 1993, Krause 1994, Long et al. 1994). Photoinhibition is therefore commonly recorded in field-grown potatoes (Somersalo and Krause 1990). Cultivated potato and the wild freezing-tolerant relatives $S$. commersonii and $S$. acaule suffer from photoinhibition if exposed to low temperature in the presence of light (Hetherington et al. 1983, Steffen and Palta 1986, 1987, 1989a,b, Steffen et al. 1989, 1995, Griffith et al. 1994). Light stress is also an important component of freezing injury in field grown potato since freezing temperatures are usually followed by bright mornings. Steffen and Palta (1989b) reported that light after a frost episode increases injury in S. acaule.

Chlorophyll fluorescence is a sensitive method for detecting changes in photosynthetic capacity due to various stresses (Bolhàr-Nordenkampf and Öquist 1993). During photoinhibition, the decline in variable to maximum fluorescence correlates with the decrease of quantum yield of $\mathrm{O}_{2}$ evolution (Demming and Björkman 1987, Krause et al. 1990). This technique has therefore been extensively used in studies on photoinhibition and has been found to be useful also in screening for freezing tolerance in potato (Sundbom et al. 1982, Smillie and Heth- 
Vol. 10 (2001): 153-163.

erington 1983, Graeves and Wilson 1987, Kristjandottir and Merker 1993).

Here we characterise the frost tolerance of S. tuberosum cultivars and compare it with that of $S$. commersonii x $S$. tuberosum hybrids. Frost tolerance is separated into two parameters: tolerance to freezing and tolerance to low temperature photoinhibition. Frost tolerance and the development of frost injury were monitored by visual scoring of plants in growth chambers and in the field, and by following the changes in fluorescence kinetics after frost treatments in the laboratory.

\section{Material and methods}

\section{Plant material}

Tubers of commercially available $S$. tuberosum cultivars, Nicola, Pito, Puikula and Timo, were obtained from the Tuber Seed Centre (Tyrnävä, Finland). The somatic hybrid, SH9A (S. commersonii PI243503 (+) S. tuberosum SPV11), was kindly provided by Dr. T. Cardi, CNR-IMOF, Research Institute for Vegetable and Ornamental Plant Breeding, Italy (Cardi et al. 1993). Potato hybrids, 1020 and 2051, were produced by selfing SH9A and characterised as freezing tolerant (1020) or freezing sensitive (2051) (Seppänen et al. 1998). The hybrids were propagated in vitro and grown for four to six weeks prior transfer to the greenhouse. In the greenhouse, all potato plants were grown in pots (diameter $15 \mathrm{~cm}$ ) containing 10:1 (v/v) peat and sand. They were maintained at $20 / 15^{\circ} \mathrm{C}$ day/night temperatures and $18 \mathrm{~h}$ photoperiod of $220 \mu \mathrm{mol} \mathrm{m} \mathrm{m}^{-2} \mathrm{~s}^{-1}$ supplied by SON-H/350 W lamps (Philips, Belgium).

\section{Controlled frost treatments in the growth chamber}

Experiment 1: Potato plants $(\mathrm{n}=3)$ were exposed to controlled frost treatments in a growth cham- ber (Weiss Bio 1300, Germany). Plants were transferred to growth chambers from greenhouse and controlled frost treatments were initiated immediately. The ambient temperature was gradually lowered from $10^{\circ} \mathrm{C}$ to the target temperature in 11 hours. Plants were exposed to the minimum temperature $\left(-3^{\circ} \mathrm{C}\right.$ or $\left.-5^{\circ} \mathrm{C}\right)$ for 2 hours before the temperature was raised to $2^{\circ} \mathrm{C}$ over 5 hours. Measurements on photosynthetic activity after freezing treatment (FR) were carried out at this point. In nature early autumn frosts take place at low light intensity or in darkness. The light intensity was therefore set to $80 \mu \mathrm{mol} \mathrm{m}^{-2} \mathrm{~s}^{-1}$ (L $36 \mathrm{~W} / 31-830$ Lumilux plus lamps, Osram, Germany) and to $40 \mu \mathrm{mol} \mathrm{m}^{-2} \mathrm{~s}^{-1}$ after the temperature had been decreased to $6^{\circ} \mathrm{C}$. After taking fluorescence measurements from low temperature treated plants, the plants were exposed to high light intensity (HL) (700 $\mu \mathrm{mol} \mathrm{m} \mathrm{m}^{-2} \mathrm{~s}^{-1}$ ) for four hours while the temperature was increased to $10^{\circ} \mathrm{C}$. The development of frost damage was followed at $15 / 10^{\circ} \mathrm{C}$ (day/night) with an $18 \mathrm{~h}$ photoperiod of 100 $\mu \mathrm{mol} \mathrm{m} \mathrm{m}^{-2} \mathrm{~s}^{-1}$ until 24 hours (RE1) and 48 hours (RE2) after controlled frost treatments.

Experiment 2: In order to minimise experimental variation in freezing and conditions of high light intensity caused by morphological differences (plant height, leaf orientation) between the genotypes, excised leaf discs were used. Three leaf discs $(\varnothing 3 \mathrm{~cm})$ from three individual plants were excised and placed in test tubes containing wet tissue at the base. The tubes were put into a controlled cooling unit (Lauda RK20 KP, Germany) at $1^{\circ} \mathrm{C}$ and the temperature was decreased to $-1^{\circ} \mathrm{C}$ within two hours. Extracellular ice formation was initiated by adding small ice crystals into the tubes. The temperature was decreased to freezing at $-3^{\circ} \mathrm{C}$ during two hours. The minimum temperature $\left(-3^{\circ} \mathrm{C}\right)$ was maintained for one hour before being increased gradually $\left(1^{\circ} \mathrm{C} / \mathrm{h}\right)$ to $4^{\circ} \mathrm{C}$ and maintained overnight. Measurements on photosynthetic activity were carried out after freezing (FR), before the leaf discs were put into petri dishes on a section of wet paper towel. The plates were then placed in ice boxes and exposed to a maximum photon flux density (PFD) of $700 \mu \mathrm{mol}$ 
Seppänen, M.M. et al. Frost tolerance of potato

$\mathrm{m}^{-2} \mathrm{~s}^{-1}$ for $4 \mathrm{~h}(\mathrm{FR}+\mathrm{HL})$. After treatment with high light intensity photosynthetic activity was measured again (FR + HL) and the leaf discs were transferred to a growth chamber at $15 / 10^{\circ} \mathrm{C}$ (day/ night) with an $18 \mathrm{~h}$ photoperiod of $100 \mu \mathrm{mol}$ $\mathrm{m}^{-2} \mathrm{~s}^{-1}$ where the recovery was followed similarly as in Experiment 1.

\section{Freezing tolerance and visual frost injury}

Freezing tolerance was measured using an ion leakage method (Seppänen et al. 1998). LT $_{50}{ }^{-}$ value (lethal temperature where $50 \%$ of ions have leaked out from the cell) was calculated as an average of at least three replicate plants by using an $\mathrm{LT}_{50}$-program (Janacek and Prasil 1991). The development of frost injury was visually evaluated similarly in growth chamber and field experiments. For visual scoring a scale from 1 to 5 was used, where 5 referred to an undamaged plant and 1 to a severely damaged plant. In the field experiment the upper and lower canopies were assessed separately. The development of frost injury was followed in 1998 and 1999 and the severity was expressed as a percentage of damaged leaf area. Air temperature was monitored at two meters height (min, max, mean), at ground level (Gmin) and inside the potato canopy during the development of frost injury.

\section{Photosynthetic activity}

Frost injury to the photosynthetic apparatus was monitored by chlorophyll a fluorescence and oxygen evolution measurements. Chlorophyll fluorescence, a variable of maximum fluorescence yield $\left(\mathrm{F}_{\mathrm{V}} / \mathrm{F}_{\mathrm{M}}\right)$, was monitored with a Hansatech fluorometer (Hansatech FMS-2) after 10-min dark adaptation. Oxygen evolution was measured with a Hansatech oxygen electrode (Hansatech Ltd., King's Lynn, U.K.) at $10^{\circ} \mathrm{C}$ under a photon flux density of $400 \mu \mathrm{mol}$ photons $\mathrm{m}^{-2} \mathrm{~s}^{-1}$.

Chlorophyll fluorescence and oxygen evolution measurements were made from three upper leaves of potato plants (Experiment 1) or from excised leaf discs (Experiment 2). Changes in $\mathrm{F}_{\mathrm{V}} / \mathrm{F}_{\mathrm{M}}$ and oxygen evolution were followed prior to and after the stress treatments: before stress treatments (C), after freezing (FR), and after freezing and high light intensity treatments (FR $+\mathrm{HL}$ ). The recovery from the stress treatments was monitored over $24 \mathrm{~h}$ (RE1) and $48 \mathrm{~h}$ (RE2) after the high light intensity treatment.

\section{Results}

\section{Freezing tolerance and visually rated frost damage}

Potato hybrids 2051, SH9A and 1020 were significantly more tolerant of freezing than $S$. $t u$ berosum cultivars Puikula, Pito and Timo (Table 1). Nicola had significantly better freezing tolerance than Puikula. However, when frost tolerance was evaluated in the growth chamber by applying both freezing and light stress, none of the potato genotypes were severely injured at $-3^{\circ} \mathrm{C}$, although the freezing temperature in the chambers was lower than the critical temperature, which was measured by ion leakage tests (Fig. 1a, Table 1).

Table 1. The freezing tolerance of cultivated potato cultivars (Puikula, Pito, Timo, Nicola), the somatic hybrid SH9A and hybrids 1020 and 2051. $\mathrm{LT}_{50}$-value is the temperature where $50 \%$ of ions have leaked from the cell. The $\mathrm{LT}_{50}$ -values are calculated from three replicates.

\begin{tabular}{ll}
\hline Potato genotype & $\mathrm{LT}_{50}$ \\
\hline Puikula & $-2.4 \mathrm{a}$ \\
Pito & $-2.5 \mathrm{ab}$ \\
Timo & $-2.6 \mathrm{ab}$ \\
Nicola & $-3.0 \mathrm{bc}$ \\
2051 & $-3.2 \mathrm{c}$ \\
SH9A & $-3.8 \mathrm{~d}$ \\
1020 & $-4.5 \mathrm{e}$ \\
\hline LSD* & 0.473 \\
\hline
\end{tabular}

* LSD = least-significant difference 
Vol. 10 (2001): 153-163.
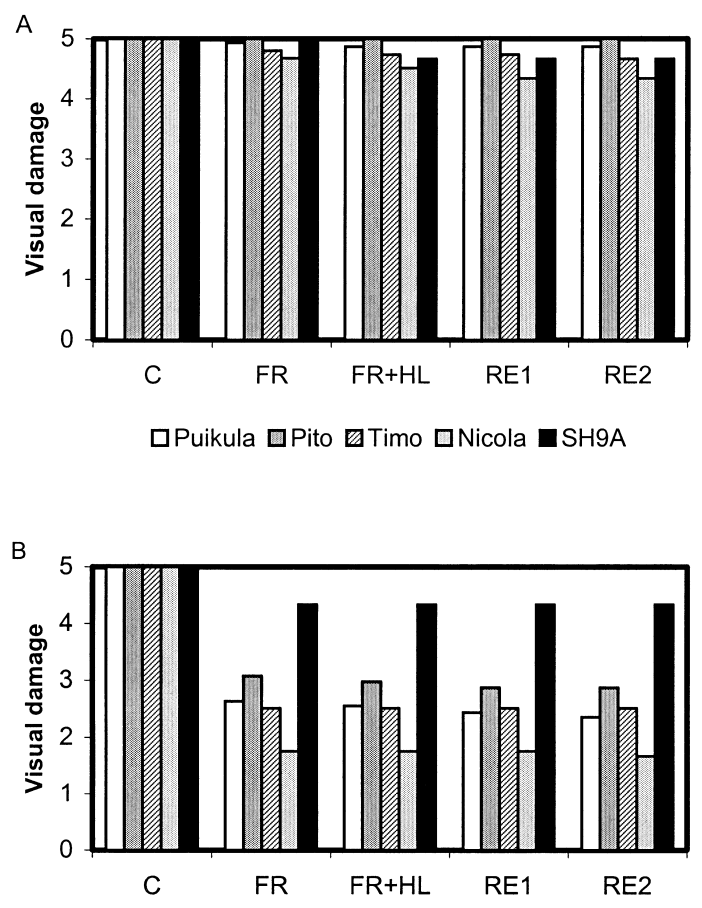

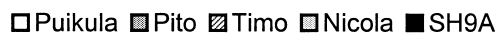

Fig. 1. The development of freezing injury under laboratory conditions during controlled night frosts. Four potato cultivars (Puikula, Pito, Timo, Nicola) and a somatic hybrid SH9A (S. commersonii (+) S. tuberosum SPV11) were exposed to a freezing night (FR) and subsequent high light intensity $\left(700 \mu \mathrm{mol} \mathrm{m} \mathrm{m}^{2} \mathrm{~s}^{-1}\right)(\mathrm{FR}+\mathrm{HL})$. After freezing and high light intensity treatment (FR + HL) the development of freezing injury was monitored over 24-hours (RE1) and 48-hours (RE2). C referes to frost injuries in conditions prior to frost treatments. Two temperatures were used in freezing treatments (FR) a) $-3^{\circ} \mathrm{C}$ and b) $-5^{\circ} \mathrm{C}$. Visual scoring: 1 - severe damage, 5 - no visual damage.

All S. tuberosum cultivars suffered from significant injury when the freezing temperature was lowered to $-5^{\circ} \mathrm{C}$ during the frost treatments (Fig. 1b). Due to the large standard deviation between the replications error bars are not shown in the figure. In the hybrid SH9A only minor injury was observed after the frost treatment.

In the field experiments, the development of frost injury was evaluated separately on leaves
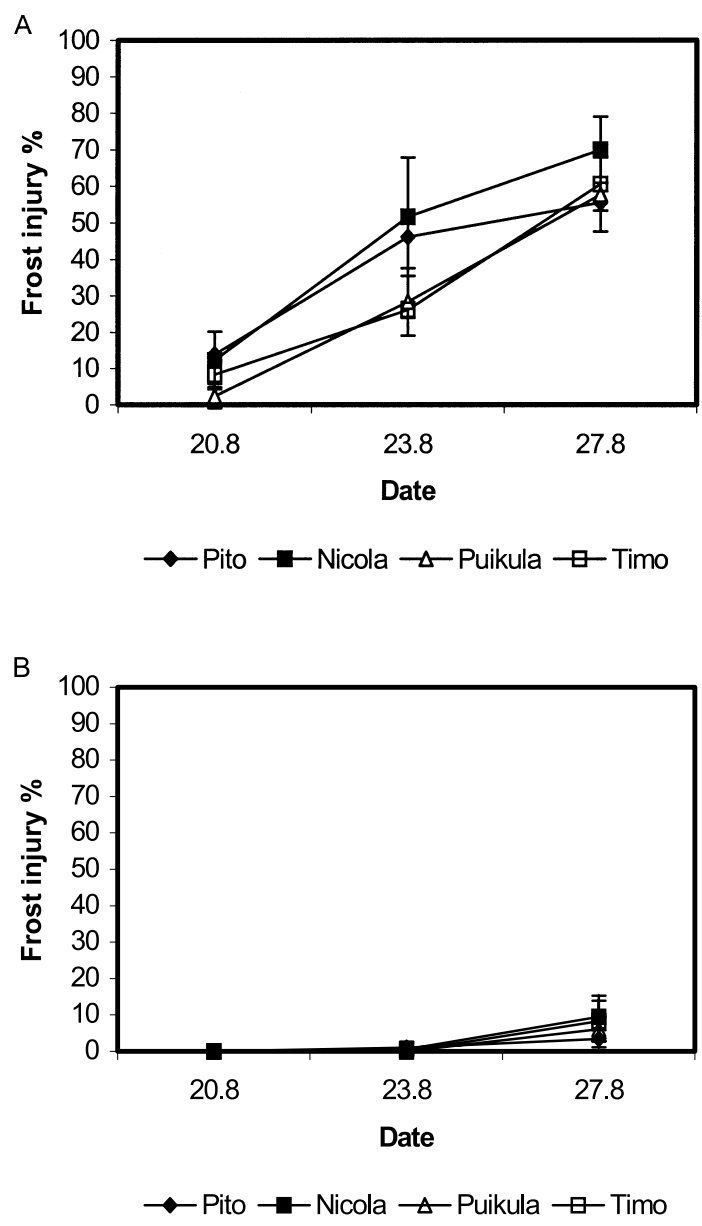

Fig. 2. The development of frost injury in a potato canopy under field conditions at Lapland Research Station in 1999. Frost injury (\%) was monitored from the upper (a) and lower (b) leaves of the canopy. See Table 2 for air temperatures during the frost period.

of the upper and lower canopy (Figs. 2a, 2b). In 1998 , the canopy was completely destroyed by night frosts on 31 August and 1 September. The first night frost lasted for 5 hours and the temperature decreased to $-4.4^{\circ} \mathrm{C}$ at ground level, to $-2.2^{\circ} \mathrm{C}$ at two meters and to $-1.4^{\circ} \mathrm{C}$ in the canopy (data not shown). During the following night, the ambient and internal canopy temperatures dropped below the lethal level to $-4.5^{\circ} \mathrm{C}$. In 1999 , frost injury began to develop slowly in the 


\section{Seppänen, M.M. et al. Frost tolerance of potato}

Table 2. The development of frost injury in Apukka, the research station of the MTT Agrifood Research Finland, during 20 to 27 August 1999. Daily maximum and minimum temperatures were monitored at two meters and at ground level (Gmin). Temperature inside the potato canopy was measured $30 \mathrm{~cm}$ above the ground. Cloudiness: 1 - clear sky, 9 - completely cloudy.

\begin{tabular}{|c|c|c|c|c|c|c|c|c|}
\hline \multirow[t]{2}{*}{ Date } & \multicolumn{5}{|c|}{$\begin{array}{c}\text { Temperature } \\
\left({ }^{\circ} \mathrm{C}\right)\end{array}$} & \multirow[t]{2}{*}{ Cloudiness } & \multirow[t]{2}{*}{$\begin{array}{c}\text { Irradiation } \\
\left(\mathrm{W} / \mathrm{m}^{2}\right)\end{array}$} & \multirow[t]{2}{*}{$\begin{array}{l}\text { Rain } \\
(\mathrm{mm})\end{array}$} \\
\hline & Mean & Max & Min & Gmin & $\begin{array}{l}\text { Canopy } \\
\text { (min) }\end{array}$ & & & \\
\hline 20 Aug & 7.3 & 14.4 & -0.8 & -3.1 & 1.0 & 1 & 204.8 & \\
\hline $21 \mathrm{Aug}$ & 7.1 & 13.6 & -0.8 & -3.8 & 0.8 & 1 & 175.2 & \\
\hline $22 \mathrm{Aug}$ & 6.4 & 13.0 & 0.2 & -2.6 & 1.9 & 7 & 138.0 & \\
\hline $23 \mathrm{Aug}$ & 6.8 & 14.8 & -0.5 & -3.4 & 1.0 & 9 & 183.9 & \\
\hline $24 \mathrm{Aug}$ & 9.1 & 17.0 & 0.4 & -2.7 & 1.7 & 8 & 101.7 & \\
\hline $25 \mathrm{Aug}$ & 11.5 & 15.6 & 9.3 & 4.8 & 11.0 & 1 & 207.3 & \\
\hline $26 \mathrm{Aug}$ & 8.5 & 16.3 & -1.3 & -4.2 & 0.1 & 1 & 192.2 & 8.7 \\
\hline 27 Aug & 11.2 & 17.3 & 1.8 & 0.2 & 1.5 & 8 & 68.1 & 14.3 \\
\hline
\end{tabular}

upper leaves immediately after the first night frost of 20 August (Fig. 2a). Injury continued to proceed slowly although several night frosts occurred during the following nights (Table 2). Within the first three days the development of frost injury was slightly faster in cultivars Pito and Nicola but after seven days there were no differences between the cultivars. Visual frost injury was monitored in the lower canopy only after the freezing temperature during the night frost was decreased to $-4.2^{\circ} \mathrm{C}$ at ground level (Fig. 2b, Table 2).

During the development of frost injury (from 20 to 27 August 1999) (Fig. 2a), air temperature in the potato canopy did not decrease below freezing (Table 2). The temperature in the canopy was higher than the minimum temperature at two meters (Min). Although potato plants were not exposed to freezing during the frost episode, bright daylight (clear sky) after the first two freezing nights may have increased injury to the canopy.

In 1999, the minimum temperature at two meters was two to three degrees higher than at ground level, forming a temperature gradient close to the soil surface. Since the position of the potato canopy in this temperature gradient may have affected the severity of frost injury, the height of the potato cultivars was plotted against the degree of frost injury (data not shown). No correlation was found $\left(\mathrm{R}^{2}=0.12\right)$, indicating that the height of the potato cultivar had no influence on frost tolerance. It also suggests that freezing injury in taller genotypes was not due to exposure to lower temperature.

\section{Tolerance to low temperature photoinhibition}

The tolerance of the photosynthetic apparatus to low temperature photoinhibition was studied by monitoring changes in variable to maximum fluorescence $\left(\mathrm{F}_{\mathrm{v}} / \mathrm{F}_{\mathrm{M}}\right)$ and oxygen evolution after controlled frost treatments. When the plants were exposed to night frost at $-3^{\circ} \mathrm{C}$, no reduction in fluorescence kinetics was detected in any of the genotypes (data not shown). When the freezing temperature during a night frost was decreased to $-5^{\circ} \mathrm{C}$, a significant reduction in $\mathrm{F}_{\mathrm{V}} / \mathrm{F}_{\mathrm{M}}$ was detected in all $S$. tuberosum cultivars. The most significant reduction was measured in Nicola $(-26 \%)$ whereas there was no change of $F_{V} / F_{M}$ in the hybrid SH9A (Table 3). In S. tuberosum cultivars the high light intensity treatment increased damage to the photosynthetic apparatus 
Vol. 10 (2001): 153-163.

Table 3. Development of the variable to maximum fluorescence $\left(\mathrm{F}_{\mathrm{v}} / \mathrm{F}_{\mathrm{M}}\right)$ in potato plants exposed to controlled frost at $-5^{\circ} \mathrm{C}$ in growth chambers (See: Material and methods; Experiment 1). $\mathrm{SE}$ - standard error of mean; $\mathrm{n}=6$. The change in $\mathrm{F}_{\mathrm{V}} / \mathrm{F}_{\mathrm{M}}$ is expressed as $\%$ from the $\mathrm{F}_{\mathrm{v}} / \mathrm{F}_{\mathrm{M}}$-value of before the treatments.

\begin{tabular}{|c|c|c|c|c|c|c|c|c|c|c|}
\hline \multirow[t]{2}{*}{ Genotype } & \multicolumn{2}{|c|}{ Before treatments } & \multicolumn{2}{|c|}{ After FR* } & \multicolumn{2}{|c|}{ After FR + HL ${ }^{* *}$} & \multicolumn{2}{|c|}{$\begin{array}{c}\text { Recovery } 24 \mathrm{~h} \\
\text { (RE1) }\end{array}$} & \multicolumn{2}{|c|}{$\begin{array}{c}\text { Recovery } 48 \mathrm{~h} \\
\text { (RE2) }\end{array}$} \\
\hline & $\mathrm{F}_{\mathrm{v}} / \mathrm{F}_{\mathrm{M}}$ & $\%$ & $\mathrm{~F}_{\mathrm{v}} / \mathrm{F}_{\mathrm{M}}$ & $\%$ & $\mathrm{~F}_{\mathrm{V}} / \mathrm{F}_{\mathrm{M}}$ & $\%$ & $\mathrm{~F}_{\mathrm{V}} / \mathrm{F}_{\mathrm{M}}$ & $\%$ & $\mathrm{~F}_{\mathrm{v}} / \mathrm{F}_{\mathrm{M}}$ & $\%$ \\
\hline Puikula & $0.85 \pm 0.00$ & 0 & $0.78 \pm 0.02$ & -9 & $0.62 \pm 0.06$ & -27 & $\dagger$ & -100 & $\dagger$ & -100 \\
\hline Pito & $0.86 \pm 0.00$ & 0 & $0.75 \pm 0.02$ & -13 & $0.62 \pm 0.06$ & -29 & $\dagger$ & -100 & $\dagger$ & -100 \\
\hline Timo & $0.86 \pm 0.00$ & 0 & $0.70 \pm 0.04$ & -18 & $0.56 \pm 0.06$ & -34 & $\dagger$ & -100 & $\dagger$ & -100 \\
\hline Nicola & $0.85 \pm 0.00$ & 0 & $0.63 \pm 0.04$ & -26 & $0.49 \pm 0.07$ & -42 & $\dagger$ & -100 & $\dagger$ & -100 \\
\hline SH9A & $0.86 \pm 0.00$ & 0 & $0.85 \pm 0.01$ & 0 & $0.84 \pm 0.01$ & -2 & $0.85 \pm 0.00$ & -1 & $0.86 \pm 0.01$ & 0 \\
\hline
\end{tabular}

$\dagger$ not assessable due to lethal injury

* FR - freezing at $-5^{\circ} \mathrm{C}$

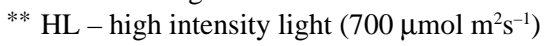

Table 4. The effect of freezing (FR) and high light intensity (HL) on the variable to maximum fluorescence and on oxygen evolution $\left(\mu \mathrm{mol} \mathrm{s}{ }^{-1} \mathrm{~m}^{2}\right)$ in potato leaf discs. The reduction of $\mathrm{F}_{\mathrm{v}} / \mathrm{F}_{\mathrm{M}}$ as $\%$ of untreated control is shown in parenthesis. Two potato cultivars Timo, Nicola and the somatic hybrid SH9A and hybrids 1020 and 2051 were examined. For fluorescence measurements SE - standard error of mean; $n=9$, and for oxygen evolution $\mathrm{SE}$ - standard error of mean; $\mathrm{n}=3$.

\begin{tabular}{|c|c|c|c|c|c|c|}
\hline \multirow[t]{2}{*}{ Genotype } & \multicolumn{2}{|c|}{ Before treatments } & \multicolumn{2}{|c|}{ After FR ${ }^{* *}$} & \multicolumn{2}{|c|}{ After FR and $\mathrm{HL}^{* *}$} \\
\hline & $\mathrm{F}_{\mathrm{V}} / \mathrm{F}_{\mathrm{M}}$ & $\begin{array}{l}\text { Oxygen } \\
\text { evolution }\end{array}$ & $\mathrm{F}_{\mathrm{V}} / \mathrm{F}_{\mathrm{M}}$ & $\begin{array}{c}\text { Oxygen } \\
\text { evolution }\end{array}$ & $\mathrm{F}_{\mathrm{V}} / \mathrm{F}_{\mathrm{M}}$ & $\begin{array}{l}\text { Oxygen } \\
\text { evolution }\end{array}$ \\
\hline 1020 & $0.85(0)$ & $18.0 \pm 0.0$ & $0.84 \quad(1.5 \pm 0.6)$ & $22.0 \pm 9.6$ & $0.71(16.9 \pm 1.5)$ & 0.00 \\
\hline 2051 & $0.86(0)$ & $14.2 \pm 1.3$ & $0.82(4.6 \pm 0.4)$ & $9.1 \pm 5.7$ & $0.68(20.6 \pm 1.4)$ & 0.00 \\
\hline SH9A & $0.86(0)$ & $13.5 \pm 0.0$ & $0.84 \quad(2.7 \pm 0.3)$ & $18.6 \pm 8.6$ & $0.71(17.3 \pm 0.8)$ & 0.00 \\
\hline Timo & $0.86(0)$ & $11.3 \pm 3.2$ & $0.69(20.0 \pm 0.2)$ & 0.00 & $0.52(39.8 \pm 2.6)$ & 0.00 \\
\hline Nicola & $0.87(0)$ & $11.3 \pm 3.2$ & $0.81 \quad(6.7 \pm 0.4)$ & 0.00 & $0.71(18.5 \pm 4.0)$ & 0.00 \\
\hline
\end{tabular}

* FR - freezing at $-3^{\circ} \mathrm{C}$

** $\mathrm{HL}$ - high intensity light $\left(700 \mu \mathrm{mol} \mathrm{m} \mathrm{m}^{2} \mathrm{~s}^{-1}\right)$

$(\mathrm{FR}+\mathrm{HL})$ and caused lethal injury within 24 hours (RE1).

To avoid supercooling and ensure complete freezing of potato leaves, leaf discs rather than entire plants were used for controlled frost experiments (Table 4). Freezing to $-3^{\circ} \mathrm{C}$ led to significant reduction in $\mathrm{F}_{\mathrm{V}} / \mathrm{F}_{\mathrm{M}}$ only in Timo. However, in both cultivars oxygen evolution decreased to zero after freezing treatment indicating that lethal injury to the photosynthetic apparatus had occurred. The photosynthesis of hybrid 2051 was also sensitive to freezing, decreasing as the oxygen evolution decreased from 14.2 to $9.1 \mu \mathrm{mol} \mathrm{s}^{-1} \mathrm{~m}^{2} .2051$ was also the most freezing sensitive potato hybrid (Table 1). For the more freezing tolerant hybrids, SH9A and 1020, no decrease in oxygen evolution was recorded after freezing (Table 4). High light intensity treatment after freezing stress (FR + HL) caused a significant reduction in $\mathrm{F}_{\mathrm{V}} / \mathrm{F}_{\mathrm{M}}$ in all genotypes studied. Oxygen evolution measurements indicated that all genotypes had undergone lethal damage to the photosynthetic apparatus. In this experiment, oxygen evolution was not monitored during recovery. 


\section{Discussion}

\section{Frost injury to membranes and to the photosynthetic apparatus}

Solanum tuberosum cultivars differed only slightly from each other in their tolerance to freezing and low temperature photoinhibition. According to results from the ion leakage tests, Nicola was most tolerant of cellular freezing. However, when the tolerance to low temperature photoinhibition was evaluated using chlorophyll fluorescence measurements, the reduction in photosynthetic efficiency was highest in Nicola. Ion leakage tests measure the tolerance of the plasma membrane to freezing (Levitt 1980) whereas chlorophyll fluorescence detects damage in photosynthetic functions (BolhàrNordenkampf and Öquist 1993). Careful analysis of both parameters in this experiment revealed that there might exist some genetic variation among $S$. tuberosum cultivars in their tolerance to freezing and photoinhibition. However, the monitored differences between the cultivars were modest and are of restricted significance for breeding programs. Also there was a discrepancy between the results on fluorescence and oxygen evolution. $\mathrm{F}_{\mathrm{V}} / \mathrm{F}_{\mathrm{M}}$ reflects the efficiency of PSII and therefore the values should be in accordance with oxygen production (Krause et al 1990). The results on oxygen evolution measurements suggest that freezing to $-3^{\circ} \mathrm{C}$ resulted in severe damage to the photosynthetic apparatus of potato cultivars. At the same time only moderate decrease in $F_{V} / F_{M}$ was detected. Similarly in potato hybrids, the production of oxygen after freezing correlated well with the $\mathrm{LT}_{50}{ }^{-}$ value determined by ion leakage tests. Taken together, the results show that especially freezing damages to photosynthetic apparatus can be detected earlier and more accurately by oxygen evolution than by changes in $\mathrm{F}_{\mathrm{v}} / \mathrm{F}_{\mathrm{M}}$.

\section{Exposure to high light intensity increases freezing injury to the photosynthetic apparatus}

High light intensity increased frost injury in all potato genotypes studied. Chlorophyll fluorescence data showed that interspecific hybrids suffered less from photoinhibition than S. tuberosum cultivars. Steffen and Palta (1986) reported similar results for the freezing tolerant wild potato species $S$. acaule. They also found that low temperature caused greater inhibition of photosynthetic capacity at low or moderate (40 and $400 \mu \mathrm{mol} \mathrm{m} \mathrm{m}^{-2} \mathrm{~s}^{-1}$ ) light levels in $S$. tuberosum. At low temperature high light intensity can cause imbalance in energy supply and consumption. As a consequence the risk for formation of reactive oxygen radicals increases (Krause 1994). Andean wild potato species have better capacity to detoxify these molecules than $S$. tuberosum (Kristjandottir and Merker 1993). Species such as $S$. commersonii can also increase this capacity when exposed to low temperature (Seppänen et al. 1998, Seppänen and Fagerstedt 2000). Thus, greater capacity to scavenge reactive oxygen radicals may explain the better tolerance of the hybrids to some extent.

\section{The mechanisms of frost injury in the potato canopy}

The mechanisms of chilling and freezing injury are significantly different. During freezing stress plants have to cope with cellular dehydration and mechanical injury, both of which are caused by growing ice crystals (Levitt 1980). Chilling injury, however, is a consequence of metabolic disturbances and accumulation of toxic by-products, such as reactive oxygen species (McKersie and Lesham 1994). In the field, potato plants can experience both chilling and freezing stresses. Cultivated potato is classified as a freezing sensitive species that can suffer from significant photoinhibition when exposed to chilling temperatures (Chen and Li 1980, Steffen and Palta 
Vol. 10 (2001): 153-163.

1986). The results of this experiment show that although the damage to the potato canopy started to develop after the ground temperature had decreased below freezing, the temperature inside the canopy was still relatively high. As a result, frost injury developed slowly, indicating that damage to the photosynthetic apparatus had occurred (Steffen and Palta 1989b). The opposite is true in years including 1998, when the frost was more severe and the temperature inside the canopy decreased below the killing temperature of potato. After such a severe night frost the entire leaf area was rapidly lost. Thus, depending on the severity of the frost, the injury to a potato canopy can be due to freezing or non-freezing temperatures. In order to improve low temperature tolerance of cultivated potato it would be important to increase tolerance to both kinds of frost injury. Potato hybrids were more tolerant to freezing and their photosynthetic apparatus suffered less damage when exposed to freezing or high light intensity stress. The result is in accordance with the earlier observations of Steffen and Palta (1986) that tolerance to freezing and low temperature photoinhibition are somewhat linked to each other and thus, both traits can be improved simultaneously in classical breeding programs. However, the nature of frost injury in the field has to be taken into consideration when molecular breeding and genetic transformation are used. Molecular techniques are often restricted to a manipulation of one tolerance mechanism at a time and for successful results it is critical to understand the primary cause of frost injury in the field.

\section{Comparison of results from controlled frost treatments and field experiments}

The results from the laboratory experiments increased the understanding of frost injury in the field. In the growth chamber frost injury started to develop at a lower temperature $\left(-5^{\circ} \mathrm{C}\right)$ than would be predicted according to the ion leakage results. However, when leaf discs were used freezing to $-3^{\circ} \mathrm{C}$ caused a significant reduction in photosynthetic capacity but no observable freezing injury. Plants can avoid ice formation to some extent by lowering the freezing point and supercooling (Levitt 1980). Supercooling requires absence of ice nucleators. In the field, however, plant leaves are colonised by epiphytic bacteria, or covered with dust or other particles that can act as ice nucleators (Lindow et al. 1982). However, the $\mathrm{LT}_{50}$-value derived by the ion leakage tests is not necessary the actual killing temperature of the plant, but rather an incidation of plant's sensitivity to freezing. Thus, the actual freezing temperatures used in the ion leakage and growth chamber experiments should not be compared without precaution.

In the field and in the laboratory exposure to bright light after freezing increased frost damage significantly. Laboratory experiments verified the sensitivity of the photosynthetic apparatus in $S$. tuberosum to freezing and high light intensity stresses. Thus, in breeding programs it is important to focus on both traits - increased low temperature tolerance of the photosynthetic apparatus and freezing tolerance.

Acknowledgements. This work was supported by a Finnish Cultural Foundation grant to M.M.S. and by the Department of Applied Biology, University of Helsinki, Finland. Mr. Pekka Kalliainen is gratefully acknowledged for his valuable help in arranging field experiments in Lapland Research Station. 
Bolhàr-Nordenkampf, H.R. \& Öquist, G. 1993. Chlorophyll fluorescence as a tool in photosynthesis recearch. In: Hall, D.O. et al. (eds.). Photosynthesis and production in a changing environment: a field and laboratory manual. Chapman \& Hall, London. p. 193-206.

Cardi, T. D., Ambrosio, F., Consoli, D., Puite, K.J. \& Ramulu, K.S. 1993. Production of somatic hybrids between frost tolerant Solanum commersonii and S. tuberosum: characterisation of hybrid plants. Theoretical and Applied Genetics 84: 193-200.

Chen, H.H. \& Li, P.H. 1980. Characteristics of cold acclimation and deacclimation in tuber bearing Solanum species. Plant Physiology 65: 1146-1148.

Demming, B. \& Björkman, O. 1987. Comparison of the effect of excessive light on chlorophyll fluorescence (77K) and photon yield of $\mathrm{O}_{2}$ evolution in leaves of higher plants. Planta 171: 171-184.

Graeves, J.A. \& Wilson, J.M. 1987. Assessment of the frost sensitivity of wild and cultivated potato species by chlorophyll fluorescence analysis. Potato Research 30: 381-395.

Griffith, M., Boese, S.R. \& Huner, N.P.A. 1994. Chilling sensitivity of the frost-tolerant potato Solanum commersonii. Physiologia Plantarum 90: 319-326.

Hetherington, S.E., Smillie, R.M., Malangba, P. \& Huamán, Z. 1983. Heat tolerance and cold tolerance of cultivated potatoes measured by the chlorophyll-fluorescence method. Planta 159: 119-124.

Huner, N.P.A., Öquist, G., Hurry, V.M., Krol, M., Falk, S. \& Griffith, M. 1993. Photosynthesis, photoinhibition and low temperature tolerance acclimation in cold tolerant plants. Photosynthesis Research 37:19-39.

Janacek, J. \& Prasil, I. 1991. Quantification of plant frost injury by nonlinear fitting and S-shaped function. Cryo-Letters 12: 42.

Krause, G., Somersalo, S., Zumbusch, E. \& Weyers, B. 1990. On the mechanism of photoinhibition in chloroplasts. Relationship between changes in fluorescence and activity of photosystem II. Journal of Plant Physiology 136: 472-479.

Krause, G.H. 1994. The role of oxygen in photoinhibition of photosynthesis. In: Foyer, C.H. \& Mullineaux, P.M. (eds.). Causes of Photooxidative Stress and Amelioration of Defense Systems in Plants. CRC Press, Boca Raton. p. 43-76.

Kristjansdottir, I.S. \& Merker, A. 1993. Temperature-related changes in chlorophyll fluorescence and contents of chlorophyll and carotenoids in Andean and European potato clones. Plant Breeding 111: 148154.

Levitt, J. 1980. Responses of plants to environmental stress. Chilling, freezing, and high temperature stresses, Ed. 2. Academic Press, New York. 497 p.

Lindow, E.E., Arny, D.C. \& Upper, C.D. 1982. Bacterial ice nucleation: a factor in frost injury in plants. Plant Physiology 70: 1084-1089.

Long, S.P., Humphries, S. \& Falkowski, P.G. 1994. Photoinhibition of photosynthesis in nature. Annual Re- view of Plant Physiology and Plant Molecular Biology 45: 633-662.

McKersie, B.D. \& Lesham, Y.Y. 1994. Stress and stress coping in cultivated plants. Kluwer Academic Publishers, Netherlands. $256 \mathrm{p}$.

Pessi, Y. 1958. Hallojen esiintymisestä ja niiden aiheuttamista vahingoista Suomessa. Acta Agralia Fennica 93: 1-44.

- 1960. Ilmasto ja kasvinviljely: opastusta kasvinviljelyn soveltamisesta ilmasto- ja sääoloihin. Maamiehen käsikirjasto 3. Kirjayhtymä Helsinki. 67 p.

Seppänen, M.M. \& Fagerstedt, K. 2000. The role of superoxide dismutase activity in response to cold acclimation in potato. Physiologia Plantarum 108: 279285.

-, Majaharju, M., Somersalo, S. \& Pehu, E. 1998. Freezing tolerance, cold acclimation and oxidative stress in potato. Paraquat tolerance is related to acclimation but is a poor indicator of freezing tolerance. Physiologia Plantarum 102: 454-460.

Smillie, R.M. \& Hetherington, S.E. 1983. Stress tolerance and stress-induced injury in crop plants measured by chlorophyll fluorescence in vivo. Plant Physiology 72: 1043-1050.

Solantie, R. 1987. Hallojen loppuminen keväällä ja alkaminen syksyllä. Meteorologisia julkaisuja 6. Ilmatieteen laitos, Helsinki. 60 p.

Somersalo, S. \& Krause, G.H. 1990. Photoinhibition at chilling temperatures and effects of freezing stress on cold acclimated spinach leaves in the field. A fluorescence study. Physiologia Plantarum 79: 617-622.

Steffen, K.L., Arora, R. \& Palta, J.P. 1989. Relative sensitivity of photosynthesis and respiration to freeze-thaw stress in herbaceous species. Importance of realistic freeze-thaw protocols. Plant Physiology 89: 13721379.

- \& Palta, J.P. 1986. Effect of light on photosynthetic capacity during cold acclimation in a cold-sensitive and a cold-tolerant potato species. Physiologia Plantarum 66: 353-359.

- \& Palta, J.P. 1987. Photosynthesis as a key process in plant response to low temperature: alteration during low temperature acclimation and impairment during incipient freeze-thaw injury. In: Li, P.H. (ed.). Plant Cold Hardiness. Liss, A.R. Inc., New York. p. 67-99.

- \& Palta, J.P. 1989a. Growth and development temperature influences level of tolerance to high light stress. Plant Physiology 91: 1558-1561.

- \& Palta, J.P. 1989b. Light stress following a frost episode influences the frost tolerance of a wild potato species. Journal of the American Society for Horticultural Science 114: 656-661.

-, Wheeler, R.M., Arora, R., Palta, J.P. \& Tibbitts, T.W. 1995. Balancing photosynthetic light-harvesting and light-utilization capacities in potato leaf tissue during acclimation to different growth temperatures. Physiologia Plantarum 94: 51-56.

Sundbom, E., Strand, M. \& Hällgren, J.-E. 1982. Temper- 
Vol. 10 (2001): 153-163.

ature-induced fluorescence changes. Screening method for frost tolerance of potato (Solanum sp.). Plant Physiology 70: 1299-1302.

Valmari, A. 1959. The effect of fertilization on the frost resistance of barley, oats, and potato. Maatalous ja Koetoiminta 13: 54-63.

- 1965 . On night frost research in Finland. Acta Agralia Fennica 107: 191-214.

\title{
SELOSTUS
}

\section{Perunan ja perunahybridien jäätymisen ja fotoinhibition kestävyys}

\author{
Mervi M. Seppänen, Oiva Nissinen ja Saija Perälä \\ Helsingin yliopisto ja MTT (Maa- ja elintarviketalouden tutkimuskeskus)
}

Tutkimuksessa vertailtiin toisiinsa neljän perunalajikkeen (Solanum tuberosum L.) (Nicola, Pito, Puikula, Timo) ja kolmen perunahybridin (S. commersonii $\mathrm{x}$ $S$. tuberosum) jäätymisen ja fotoinhibition kestävyyttä. Jäätymisen kestävyyttä mitattiin ionivuototestien avulla, ja yhteyttämiskoneiston herkkyyttä alhaisille lämpötiloille ja korkealle valolle tutkittiin seuraamalla klorofyllifluoresenssissa ja hapentuotannossa tapahtuvia muutoksia.

Korkea valon intensiteetti heti jäätymisen jälkeen lisäsi hallavaurioita kaikilla tutkituilla perunagenotyypeillä. Kaikki perunahybridit kestivät paremmin jäätymistä ja korkeaa valoa kuin $S$. tuberosum lajikkeet. Peltokokeissa hallavauriomekanismit vaihtelivat vuosittain hallan ankaruuden mukaan. Syksyn 1999 yöhallojen yhteydessä lämpötila perunakasvuston sisällä oli huomattavasti korkeampi kuin maan- pinnalta mitattu lämpötila. Itse asiassa kasvuston lämpötila ei koskaan laskenut alle perunan kuolettavan lämpötilan, joka vaihteli lajikkeen mukaan $-2.5^{\circ} \mathrm{C}$ :sta $-3.0^{\circ} \mathrm{C}$ :een. Tämän seurauksena hallavauriot levisivät kasvustossa hitaasti, mikä viittaa yhteyttämiskoneissa tapahtuneisiin vaurioihin sekä sen seurauksena tapahtuneeseen hapen radikaalien kertymiseen. Mikäli yölämpötila laski maanpinnalla ja kasvuston sisällä $-4^{\circ} \mathrm{C}$ :een, kasvusto tuhoutui nopeasti. Tämän mukaan korkea valon intensiteetti ja alhainen lämpötila (jäätyminen tai vilutus) voivat yhdessä aiheuttaa hallavaurioita. Kun pyritään parantamaan perunan kylmänkestävyyttä, on tärkeää kiinnittää huomiota molempiin stresseihin, ja ottaa huomioon etenkin korkean valon aikaansaama hallavaurioiden lisääntyminen. 